\title{
Penerapan Integrasi Model Pembelajaran Group Investigation (Gi) dan Inkuiri Terbimbing Berbasis Lesson Study
}

\author{
Indah Panca Pujiastuti \\ Program Studi Pendidikan Biologi FMIPA Universitas Sulawesi Barat \\ e-mail: indah_panca@yahoo.co.id
}

\begin{abstract}
Abstrak
Sebuah realita berdasarkan hasil observasi yang dilakukan peneliti pada kelas X-IPA 1 MA Negeri 3 Malang memperlihatkan bahwa siswa jarang menggunakan laboratorium untuk kegiatan praktikum biologi, sehingga kualitas keterampilan kerja ilmiah siswa masih tergolong rendah. Salah satu cara yang dapat meningkatkan kerja ilmiah biologi siswa adalah dengan menerapkan integrasi model pembelajaran Group Investigation (GI) dan inkuiri terbimbing berbasis Lesson Study (LS). Penelitian ini bertujuan untuk meningkatkan keterampilan kerja ilmiah biologi siswa kelas X-IPA 1 MA Negeri 3 Malang. Penelitian ini merupakan Penelitian Tindakan Kelas (PTK) yang berbasis Lesson Study (LS) dan dilaksanakan dalam 2 siklus, serta melalui tahapan plan, do, dan see. Berdasarkan hasil penelitian dapat disimpulkan bahwa terjadi peningkatan keterampilan kerja ilmiah biologi siswa yang dapat ditunjukkan dengan peningkatan rerata klasikal siklus I sebesar 78,38 menjadi 93 di siklus II.
\end{abstract}

Kata kunci : Group Investigation, inkuiri terbimbing, Lesson Study, keterampilan kerja ilmiah

\section{PENDAHULUAN}

Pendidikan berperan penting dalam mempersiapkan sumber daya manusia yang berkualitas. Sebuah realita berdasarkan hasil observasi yang dilakukan peneliti pada kelas XIPA 1 MA Negeri 3 Malang memperlihatkan bahwa siswa jarang menggunakan laboratorium untuk kegiatan praktikum biologi, sehingga kualitas keterampilan kerja ilmiah siswa masih tergolong rendah. Salah satu cara yang dapat meningkatkan kerja ilmiah biologi siswa adalah dengan menerapkan integrasi model pembelajaran Group Investigation (GI) dan inkuiri terbimbing berbasis Lesson Study (LS).

Group Investigation adalah strategi pembelajaran yang dirancang agar siswa bekerja dalam kelompok untuk memecahkan masalah dan mengembangkan keterampilan meneliti. Tiap kelompok diberi tanggung jawab untuk memilih topik yang diminati, membagi tugas-tugas menjadi sub-sub topik, dan menentukan cara melaksanakan penelitian sub-sub topik tersebut. Mereka juga mengintegrasikan materi sub-sub topik untuk menyusun laporan kelompok. Laporan hasil kerja kelompok dilaporkan ke semua anggota kelas (diskusi kelas). Tes diadakan setelah diskusi kelas, dan hasilnya berupa rata-rata skor tiap kelompok yang diumumkan kepada seluruh siswa (Susanto, 2006). Nurhadi (2002) menjelaskan bahwa model GI melibatkan siswa sejak perencanaan, baik dalam menentukan topik maupun cara untuk mempelajarinya melalui investigasi.

Pavelich dan Abraham (1977) dalam Taufiq (2012) menyatakan bahwa pembelajaran dengan metode inkuiri terbimbing memberikan kebebasan siswa untuk memilih atau mengemukakan masalah, merencanakan eksperimen, menganalisis data, dan menyimpulkan. 
Pembelajaran dengan inkuiri terbimbing, pemilihan masalah dan rencana eksperimen dilakukan oleh guru, sedangkan analisis dan membuat kesimpulan dilakukan oleh siswa.

Integrasi model pembelajaran GI dan inkuiri terbimbing adalah metode pembelajaran dengan sintaks sebagai berikut. Tahap I: Mengidentifikasi topik dan mengorganisasikan siswa ke dalam kelompok (integrasi GI dan inkuiri terbimbing). Tahap II: Diskusi masalah (inkuiri terbimbing). Tahap III: Merencanakan tugas-tugas belajar (integrasi GI dan inkuiri terbimbing). Tahap IV: Melaksanakan investigasi (integrasi GI dan inkuiri terbimbing). Tahap V: Menyiapkan laporan akhir (GI). Tahap VI: Mempresentasikan laporan akhir (GI). Tahap VII: Kesimpulan (GI). Tahap VIII: Evaluasi (GI). Tahap IX: Ekstensi/ pengulangan (inkuiri terbimbing). Tahap X: Penghargaan kelompok (GI).

Lesson Study (LS) merupakan suatu bentuk utama peningkatan kualitas pembelajaran dan pengembangan keprofesionalan guru yang dipilih oleh guru-guru di Jepang. Dalam melakukan Lesson Study, guru secara kolaboratif dalam: (1) mempelajari kurikulum, merumuskan tujuan pembelajaran, (2) merancang pembelajaran untuk mencapai tujuan, (3) melaksanakan dan mengamati suatu research lesson (pembelajaran yang dikaji), dan (4) melakukan refleksi untuk mendiskusikan pembelajaran yang dikaji, menyempurnakannya dan merencanakan pembelajaran berikutnya. Tahap-tahap pelaksanaan lesson study adalah perencanaan (plan), pelaksanaan (do), dan refleksi (see) (Susilo, 2011).

Penelitian ini bertujuan untuk meningkatkan keterampilan kerja ilmiah biologi siswa kelas X-IPA 1 MA Negeri 3 Malang melalui penerapan integrasi model pembelajaran Group Investigation (GI) dan inkuiri terbimbing berbasis Lesson Study (LS). Beberapa penelitian yang berkaitan dengan GI telah dilakukan untuk meningkatkan kerja ilmiah dan hasil belajar Biologi. Salah satu contohnya adalah penelitian yang telah dilakukan oleh Nurlitasari, pada tahun 2007 dengan judul "Penerapan Pembelajaran Kooperatif Model Group Investigation (GI) untuk Meningkatkan Kerja Ilmiah dan Hasil Belajar Siswa dalam Pembelajaran Biologi Kelas X.1 SMA Laboratorium Universitas Negeri Malang". Hasil penelitian Nurlitasari menunjukkan keberhasilan tindakan, yaitu pada hasil kerja ilmiah siswa dari siklus I ke siklus II mengalami peningkatan sebesar $20 \%$ untuk indikator merencanakan penyelidikan ilmiah, $25 \%$ untuk indikator melaksanakan penyelidikan ilmiah, dan 4\% untuk indikator mengkomunikasikan hasil penyelidikan ilmiah. Hasil belajar Biologi juga mengalami peningkatan dari siklus I ke siklus II sebesar $2,1 \%$.

Penelitian yang dilakukan oleh Taufiq (2012) dengan judul "Penggunaan Metode Inkuiri berbasis Lesson Study (LS) untuk Meningkatkan Proses dan Hasil Belajar Biologi pada Siswa Kelas X SMA Negeri Talun Kabupaten Blitar" juga menunjukkan adanya peningkatan hasil belajar siswa. Hasil belajar dari siklus I $(66,6 \%)$ ke siklus II $(83,3 \%)$ terjadi peningkatan sebesar $16,7 \%$.

\section{METODE PENELITIAN}

Penelitian ini menggunakan pendekatan kualitatif karena data yang diperoleh berupa kata-kata atau kalimat sedangkan data yang berupa angka akan diolah dan dianalisis menggunakan kata-kata. Jenis penelitiannya menggunakan Penelitian Tindakan Kelas (PTK), yang dilakukan dalam rangka meningkatkan hasil praktik pembelajaran di sekolah. PTK dilakukan dalam siklus yang terdiri dari 4 tahap, yaitu tahapan perencanaan tindakan (planning), pelaksanaan tindakan (action), observasi (observation), dan refleksi (reflection). Apabila siklus pertama belum tercapai keberhasilan, maka berlanjut pada 2 siklus. Dalam setiap siklus terdapat kegiatan Lesson Study yang memiliki 3 tahapan, yaitu plan, do, dan see. Peneliti dibantu oleh 3 orang rekan peneliti dan guru bidang studi Biologi untuk bertindak sebagai observer.

Arikunto (2013) menyatakan bahwa instrumen penelitian adalah alat atau fasilitas yang digunakan oleh peneliti dalam mengumpulkan data agar pekerjaannya lebih mudah dan hasilnya 


\section{JURNAL SAINTIFIK VOL.2 NO.1, JANUARI 2016}

lebih baik, dalam arti lebih cermat, lengkap, dan sistematis, sehingga mudah diolah. Instrumen penelitian yang digunakan dalam penelitian ini adalah untuk mengukur peningkatan keterampilan kerja ilmiah siswa.

Analisis data dalam penelitian ini dilakukan oleh peneliti. Teknik analisis data yang digunakan adalah analisis data kualitatif-kuantitatif. Data yang dianalisis berupa data keterampilan kerja ilmiah yang dikumpulkan menggunakan lembar observasi penilaian kerja ilmiah siswa. Peningkatan kerja ilmiah yang dicapai oleh siswa dihitung berdasarkan rumus menurut Arikunto (2013) yaitu sebagai berikut.

$$
\text { Persentase kerja ilmiah siswa }=\frac{\sum \text { skor yang dicapai }}{\sum \text { skormaksimum }} \times 100 \%
$$

Kriteria persentase kerja ilmiah siswa dapat dilihat pada Tabel 2.1

Tabel 1. Kriteria Persentase Kerja Ilmiah Siswa

\begin{tabular}{cccc}
\hline $\begin{array}{c}\text { Persentase } \\
\text { Keberhasilan } \\
\text { Tindakan }\end{array}$ & $\begin{array}{c}\text { Taraf } \\
\text { Keberhasilan }\end{array}$ & $\begin{array}{c}\text { Nilai dengan } \\
\text { Angka }\end{array}$ & $\begin{array}{c}\text { Nilai dengan } \\
\text { Huruf }\end{array}$ \\
\hline $86 \%-100 \%$ & Sangat baik & 4 & $\mathrm{~A}$ \\
\hline $76 \%-85 \%$ & Baik & 3 & $\mathrm{~B}$ \\
\hline $60 \%-75 \%$ & Cukup & 2 & $\mathrm{C}$ \\
\hline $55 \%-59 \%$ & Kurang & 1 & $\mathrm{D}$ \\
\hline$<54 \%$ & Kurang sekali & 0 & $\mathrm{E}$ \\
\hline
\end{tabular}

Sumber: Purwanto (2009)

\section{HASIL DAN PEMBAHASAN}

Data hasil keterampilan kerja ilmiah siswa yang diperoleh selama pelaksanaan tindakan dan observasi siklus I dan siklus II kemudian dianalisis sehingga dapat dilihat pada Tabel 2 berikut.

Tabel 2. Perbandingan Hasil Keterampilan Kerja Ilmiah Siswa

\begin{tabular}{llccccc}
\hline & & \multicolumn{2}{c}{ Siklus I } & \multicolumn{2}{c}{ Siklus II } & $\begin{array}{c}\text { Selisih } \\
\text { rerata }\end{array}$ \\
\cline { 2 - 5 } No. & Indikator Kerja Ilmiah & $\begin{array}{c}\text { Rerata } \\
\text { indikator }\end{array}$ & $\begin{array}{c}\text { Kategori } \\
\text { keberhasila } \\
\text { n tindakan }\end{array}$ & $\begin{array}{c}\text { Rerata } \\
\text { indikator }\end{array}$ & $\begin{array}{c}\text { Kategori } \\
\text { keberhasila } \\
\text { n tindakan }\end{array}$ & \\
\hline 1. & $\begin{array}{l}\text { Merencanakan } \\
\text { penyelidikan ilmiah }\end{array}$ & 90,5 & $\begin{array}{c}\text { Sangat } \\
\text { baik }\end{array}$ & 96 & $\begin{array}{c}\text { Sangat } \\
\text { baik }\end{array}$ & 5,5 \\
\hline 2. & $\begin{array}{l}\text { Melaksanakan } \\
\text { penyelidikan ilmiah }\end{array}$ & 91 & $\begin{array}{c}\text { Sangat } \\
\text { baik }\end{array}$ & 97 & $\begin{array}{c}\text { Sangat } \\
\text { baik }\end{array}$ & 6 \\
\hline 3. & $\begin{array}{l}\text { Mengkomunikasikan } \\
\text { hasil penyelidikan } \\
\text { ilmiah }\end{array}$ & 81 & $\begin{array}{c}\text { Sangat } \\
\text { baik }\end{array}$ & 90 & $\begin{array}{c}\text { Sangat } \\
\text { baik }\end{array}$ & 9 \\
\hline 4. & Bersikap ilmiah & 53 & Cukup & 88 & $\begin{array}{c}\text { Sangat } \\
\text { baik }\end{array}$ & 35 \\
\hline & Rerata kerja ilmiah & 78,38 & Baik & 93 & $\begin{array}{c}\text { Sangat } \\
\text { baik }\end{array}$ & 14,62 \\
\hline \multicolumn{1}{c}{ Ketuntasan } & $88 \%$ & & $100 \%$ & & \\
\hline
\end{tabular}


Adapun gambar dari perbandingan hasil keterampilan kerja ilmiah siswa adalah sebagai

berikut.

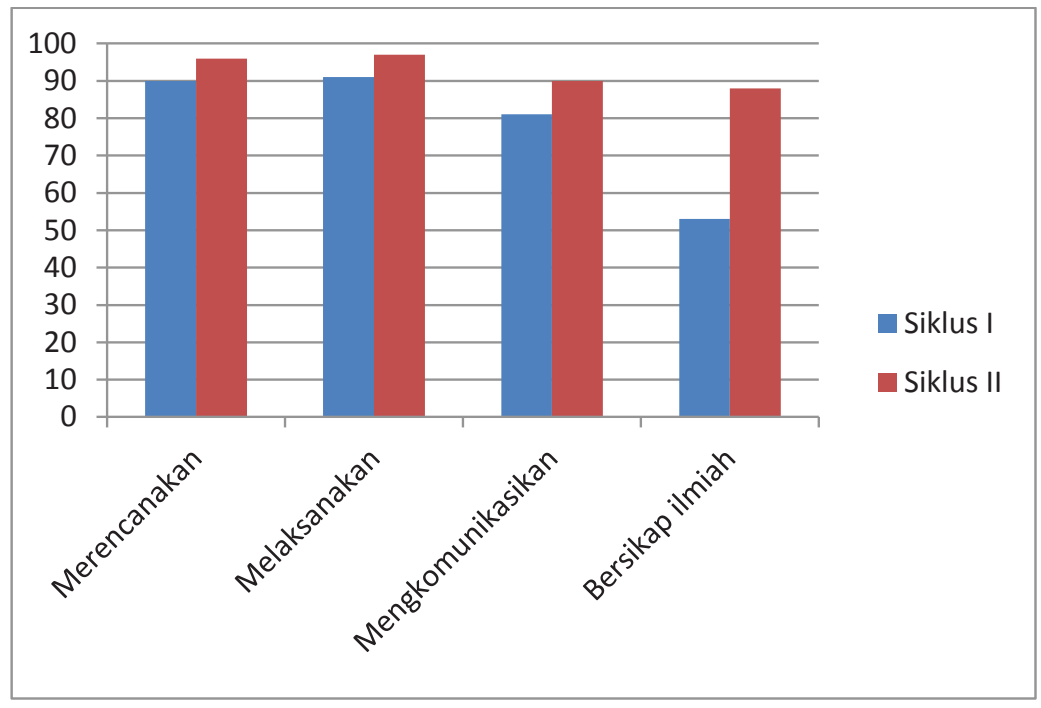

Gambar 1. Perbandingan Hasil Keterampilan Kerja Ilmiah Siswa

Berdasarkan Tabel dan Gambar di atas, diperoleh data bahwa rerata keterampilan kerja ilmiah siswa mengalami peningkatan 14,62 poin dari siklus I $(78,38)$ dengan ketuntasan $88 \%$ ke siklus II (93) dengan ketuntasan 100\%. Peningkatan indikator yang terlihat tajam adalah pada indikator bersikap ilmiah. Pada siklus I mempunyai skor rerata 53 meningkat ke siklus II menjadi 88.

Susanto (1999) menjelaskan bahwa Biologi adalah ilmu tentang makhluk hidup. Prinsip dan prosedur yang digunakan untuk mempelajari Biologi adalah kerja ilmiah dan keterampilan motorik dalam mengoperasikan peralatan yang diperlukan dalam penyelidikan ilmu yang diterapkan. Berbagai keterampilan proses mengembangkan kecakapan hidup (life skill) bahkan kecakapan yang dipakai seumur hidup (long life skill), misalnya kecakapan observasi, memecahkan masalah secara ilmiah, berpikir logis, dan sebagainya. Puskur (2002) menambahkan bahwa di dalam sistem penilaian Biologi juga harus mengukur kemampuan siswa dalam melaksanakan keterampilan proses ilmiah dan menggunakan metode ilmiah.

Indikator-indikator dalam kerja ilmiah adalah sebagai berikut.

1. Merencanakan penyelidikan ilmiah

Indikator merencanakan penyelidikan ilmiah menuntut agar dapat mengidentifikasi masalah-masalah yang perlu diteliti, merumuskan tujuan penelitian, menentukan langkahlangkah kerja, menetapkan cara memperoleh data yang sesuai, dan menetapkan cara menganalisis data. Lembar observasi kerja ilmiah siswa dapat menunjukkan rerata untuk indikator merencanakan penyelidikan ilmiah pada siklus I adalah 90,5 dengan kategori sangat baik. Sedangkan pada siklus II, indikator merencanakan penyelidikan ilmiah meningkat menjadi 96 dengan kategori sangat baik.

Adanya peningkatan rerata untuk indikator merencanakan penyelidikan ilmiah ini karena siswa yang tadinya belum begitu memahami langkah-langkah pembelajaran menjadi lebih paham. Sehingga siswa mampu mengidentifikasi masalah-masalah yang perlu diteliti, merumuskan tujuan penelitian, menentukan langkah-langkah kerja, menetapkan cara memperoleh data yang sesuai, dan menetapkan cara menganalisis data.

Peningkatan pelaksanaan tahap merencanakan penyelidikan ilmiah ini sesuai dengan hasil penelitian yang dilakukan oleh Nurlitasari (2007), yang menyatakan bahwa terjadi 
JURNAL SAINTIFIK VOL.2 NO.1, JANUARI 2016

peningkatan persentase dari siklus I ke siklus II pada tahap merencanakan penyelidikan ilmiah sebesar 20\%. Nurhadi (2004) menambahkan bahwa model GI melibatkan siswa sejak perencanaan, baik dalam penentuan topik maupun cara untuk mempelajarinya melalui investigasi.

\section{Melaksanakan penyelidikan ilmiah}

Indikator melaksanakan penyelidikan ilmiah menuntut siswa agar dapat mengambil data dengan benar, menganalisis data, dan menyimpulkan hasil penelitian. Lembar observasi kerja ilmiah siswa dapat menunjukkan rerata untuk indikator melaksanakan penyelidikan ilmiah pada siklus I adalah 91 dengan kategori sangat baik. Siklus II untuk indikator melaksanakan penyelidikan ilmiah meningkat menjadi 97 dengan kategori sangat baik. Rerata pada siklus II ini dapat juga diartikan bahwa hampir semua siswa di kelas X-IPA 1 telah melaksanakan kegiatan pengamatan dengan kategori sangat baik.

Adanya peningkatan rerata untuk indikator melaksanakan penyelidikan ilmiah ini karena siswa sangat antusias dengan pelaksanaan investigasi. Sehingga siswa mampu mengambil data yang benar, menganalisis data, dan menyimpulkan hasil penelitian. Meskipun pada siklus I ada beberapa siswa yang kurang memahami dengan langkah- langkah pembelajaran selama kegiatan investigasi, namun guru selalu mendampingi siswa dan menanyakan hal-hal yang belum dimengerti siswa.

Peningkatan pada tahap pelaksanaan penyelidikan ilmiah pada penelitian ini sejalan dengan penelitian yang dilakukan oleh Nurlitasari (2007), bahwa telah terjadi peningkatan kerja ilmiah dari siklus I ke siklus II sebesar 25\%. Dewi (2009) menyebutkan bahwa salah satu keuntungan pembelajaran kooperatif model Group Investigation (GI) adalah meningkatkan kemandirian siswa karena pembelajaran ini menyediakan banyak ruang bagi siswa untuk mengambil keputusan.

Kendala yang dihadapi siswa pada saat kegiatan investigasi siklus I adalah siswa kurang terampil dalam mengoperasikan mikroskop. Sehingga hampir 1 jam pelajaran pertama, siswa belum ada yang menemukan jenis-jenis Protista yang akan diamati. Namun setelah beberapa saat kemudian, siswa mulai menemukan jenis-jenis Protista yang akan diamati.

\section{Mengkomunikasikan hasil penyelidikan ilmiah}

Indikator mengkomunikasikan hasil penyelidikan ilmiah menuntut siswa agar dapat mengkomunikasikan masalah penelitian secara jelas dalam laporan, menjelaskan data baik secara lisan maupun tulisan, mengkomunikasikan kesimpulan dan hasil temuan penelitian, dan mencantumkan referensi yang dikutip dengan format yang benar. Lembar observasi kerja ilmiah siswa dapat mengetahui rerata untuk indikator mengkomunikasikan hasil penyelidikan ilmiah pada siklus I adalah 81 dengan kategori sangat baik. Indikator melaksanakan penyelidikan ilmiah meningkat menjadi 90 dengan kategori sangat baik pada pelaksanaan tindakan siklus II.

Peningkatan rerata untuk indikator melaksanakan penyelidikan ilmiah ini karena siswa telah terbiasa di dalam penggunaan mikroskop dan mencari jenis-jenis spesimen amatan. Pelaksanaan indikator mengkomunikasikan hasil penyelidikan ilmiah di siklus I, selain penyaji, ada beberaoa siswa lainnya yang masih terlihat canggung dalam mengkomunikasikan hasil temuan mereka. Padahal pada saat itu guru menghampiri semua kelompok dan guru melihat bahwa tiap kelompok menemukan jenis-jenis Protista yang beraneka ragam. Siswa masih nampak malu dalam mengkomunikasikan hasil temuan mereka. Salah satu penyebabnya adalah karena beberapa siswa tersebut baru pertama kali melakukan kegiatan presentasi selama proses pembelajaran yang telah dilakukan.

Pelaksanaan indikator mengkomunikasikan hasil penyelidikan ilmiah di siklus II, selain penyaji, hampir semua siswa sudah berani mengkomunikasikan hasil temuan mereka. Hal ini karena siswa sudah terbiasa dengan kegiatan presentasi yang dilakukan. Pengalaman melakukan kegiatan presentasi pada siklus I cukup memotivasi siswa untuk meningkatkan hasil kerja ilmiah siswa pada indikator mengkomunikasikan hasil penyelidikan ilmiah. Pelaksanaan presentasi ini 
sesuai dengan Nurhadi (2004) bahwa di dalam penyajian hasil akhir kelompok menyajikan suatu presentasi yang menarik dari berbagai topik yang telah dilakukan sehingga siswa harus benar-benar mempersiapkannya.

Adanya peningkatan di dalam tahap mengkomunikasikan hasil penyelidikan ilmiah ini sejalan dengan penelitian yang telah dilakukan oleh Nurlitasari (2007:58) bahwa terdapat peningkatan dari siklus I ke siklus II sebesar 4\%.

\section{Bersikap ilmiah}

Indikator bersikap ilmiah menuntut siswa agar berani dan santun dalam mengajukan pertanyaan dan berargumentsi, bekerja sama, berpendapat secara ilmiah da kritis, berani mengusulkan perbaikan atas suatu kondisi dan bertanggung jawab atas usulannya, serta menghargai pendapat yang lain. Lembar observasi kerja ilmiah siswa dapat mengetahui rerata untuk indikator bersikap ilmiah pada siklus I adalah 53 dengan kategori cukup. Indikator bersikap ilmiah ini kemudian meningkat menjadi 88 dengan kategori sangat baik pada pelaksanaan tindakan siklus II.

Adanya peningkatan rerata untuk indikator bersikap ilmiah ini karena siswa telah terbiasa di dalam kegiatan bersikap ilmiah. Sehingga bisa diperbaiki dan ditingkatkan di siklus II. Menurut Dimyati dan Mudjiono (2009) variasi pembelajaran perlu dilakukan untuk meningkatkan motivasi belajar. Sehingga seharusnya dilakukan diskusi yang bervariasi agar motivasi siswa meningkat dalam melaksanakan tahapan kerja ilmiah ini.

Irwandi (2007) menyatakan bahwa melalui metode inkuiri, siswa belajar memecahkan masalah, berpikir secara kritis dan kreatif sehingga siswa akan terbiasa bersikap seperti para ilmuan. Metode inkuiri memerlukan pengalaman yang nyata karena siswa dituntut menemukan konsep, pada pendekatan ini guru hanya berperan sebagai pemberi permasalahan serta memberikan kepada siswanya. Metode ini menekankan kemampuan siswa untuk melakukan eksplorasi, observasi, dan investigasi atas bimbingan guru. Dalam pembelajaran inkuiri terbimbing, guru yang memilih masalah dan merencanakan eksperimen, sedangkan analisis data dan penyimpulan data dilakukan sendiri oleh siswa.

\section{KESIMPULAN}

Kesimpulan dalam penelitian ini adalah terjadi peningkatan keterampilan kerja ilmiah siswa kelas X-IPA 1 MA Negeri 3 Malang melalui integrasi model pembelajaran Group Investigation (GI) dan inkuiri terbimbing yang berbasis lesson study sebesar 14,62. Rerata keterampilan kerja ilmiah pada siklus I adalah 78,38 dengan ketuntasan $88 \%$, sedangkan rerata pada siklus II adalah 93, dengan ketuntasan 100\%.

\section{DAFTAR PUSTAKA}

Arikunto, Suharsimi. 2013. Dasar-Dasar Evaluasi Pendidikan. Jakarta: Bumi Aksara

Dewi, Jini Apriska. 2009. Penerapan Pembelajaran Kooperatif Model Group Investigation (GI) melalui Pendekatan Problem Based Learning (PBL) untuk Meningkatkan Keterampilan Kerja Ilmiah dan Hasil Belajar Biologi Siswa Kelas X SMA Negeri 4 Malang. Skripsi. Tidak diterbitkan. Malang: Universitas Negeri Malang.

Dimyati dan Mudjiono. 2009. Belajar dan pembelajaran. Jakarta: PT Rineka Cipta. 


\section{JURNAL SAINTIFIK VOL.2 NO.1, JANUARI 2016}

Nurhadi. 2002. Pendekatan Kontekstual (Contextual Teaching and Learn- ing/CTL). Jakarta: Departemen Pendidikan Nasional, Dirjen Dikdasmen, Direktorat Pendidikan Lanjutan Pertama.

Nurhadi; Yasin, Burhan; dan Senduk, Agus Gerrad. 2004. Pembelajaran Konteks- tual (Contextual Teaching and Learning/CTL) dan Penerapannya dalam KBK. Malang: UM Press.

Nurlitasari, Dewi. 2007. Penerapan Pembelajaran Kooperatif Model Group Investigation (GI) untuk Meningkatkan Kerja Ilmiah dan Hasil Belajar Siswa dalam Pembelajaran Biologi Kelas X.1 SMA Laboratorium Universitas Negeri Malang. Skripsi. Tidak diterbitkan. Malang: Universitas Negeri Malang.

Puskur. 2002. Kurikulum Berbasis Kompetensi: Kegiatan Belajar Mengajar. Jakarta: Balitbang Depdiknas.

Susanto, Pudyo. 1999. Strategi Pembelajaran Biologi di Sekolah Menengah. Malang: FMIPA UM.

Susanto, Pudyo. 2006. Buku Petunjuk Teknis Praktik Pengalaman Lapangan Bidang Studi Pendidikan Biologi. Malang: UPT PPL UM.

Taufiq. 2012. Penggunaan Metode Inkuiri berbasis Lesson Study (LS) untuk meningkatkan Proses dan Hasil Belajar Biologi pada Siswa Kelas X SMA Negeri Talun Kabupaten Blitar. Tesis. Tidak Diterbitkan. PPs UM. 